Situs Yomokho di Distrik Sentani Timur, Kabupaten Jayapura 27-34

\title{
SITUS YOMOKHO DI DISTRIK SENTANI TIMUR, KABUPATEN JAYAPURA
}

\author{
Hari Suroto* \\ Balai Arkeologi Jayapura, Jalan Isele, Waena, Jayapura; \\ Telepon (096) 7572467; Facsimile (096) 7572467
}

Artikel masuk pada 8 Desember 2011

Artikel selesai disunting pada 18 Maret 2012

\begin{abstract}
Abstrak. Penelitian situs Yomokho ditujukan untuk mengungkapkan bentuk kehidupan manusia melalui materi budaya yang terkandung di dalam tanah. Teknik pengumpulan data dilakukan dengan studi pustaka, survei, dan ekskavasi. Data yang terjaring dari survei adalah konsentrasi himpunan cangkang moluska pada sejumlah bagian bukit, tonggak hunian, dan struktur jajaran batu. Data ekskavasi berupa fragmen gerabah, manik-manik, cangkang moluska, arang, tulang binatang dan manusia, serta lapisan budaya yang tebal. Hasil analisis artefaktual memberi gambaran perilaku dan pemanfaatan situs oleh masyarakat masa perundagian, sedangkan analisis kontekstual memperkuat dugaan bahwa situs tersebut merupakan bekas pemukiman.
\end{abstract}

Kata kunci: alimentasi, penguburan, manik-manik, alat tukar, teknik berburu dan menangkap ikan, pemukiman, kawasan pesisir, interaksi budaya

Abstract. EXCAVATION AT YOMOKHO IN EAST SENTANI DISTRICT. The objective of Yomokho research is to uncover the form of human life by studying its cultural material hidden underground. The data were collected by means of literature study, survey and excavation. The survey resulted concentration of mollusc shells assemblages on a number of hill sections, house poles and structures of paving stones. The excavation unearthed potsherd, beads, mollusc shells, charcoal, animal and human bones, and a thick cultural layer. Results of artefactual analysis depict the behavior and site utilization by pre-metal age people, while contextual analysis strengthens the case that the site is a former settlement.

Keywords: alimentation, burial, beads, medium of exchange, hunting and fishing techniques, coastal region, cultural interaction

\section{A. Pendahuluan}

Danau Sentani memiliki luas 25,5 $\mathrm{Km}^{2}$ atau sekitar 9.630 ha dan kedalamannya bervariasi hingga mencapai 140 meter. Kawasan Danau Sentani mulai dikenal masyarakat luar setelah naturalis Belanda melakukan ekspedisi di wilayah ini. Ekspedisi yang dilakukan oleh Wichman 1903 di Danau Sentani telah menemukan artefak Dong Son berupa kapak upacara. Sementara itu de

* Penulis adalah staf peneliti pada Balai Arkeologi Jayapura, email: mbah_tho@yahoo.com 
Bruyn yang melakukan ekspedisi pada 1959 berhasil menemukan dua buah mata pisau perunggu (Soejono 1994, 33).

Survei yang dilakukan Balai Arkeologi Jayapura pada 2010 dilatarbelakangi oleh informasi dari masyarakat bahwa di kawasan Danau Sentani masih banyak situs dan tinggalan arkeologi yang perlu diteliti. Dalam survei ini, Tim Peneliti Balai Arkeologi Jayapura berhasil menemukan Situs Pulau Kwadeware (Marweri Urang), Situs Pulau Mantai serta Situs Gua Rukhabulu Awabhu, Gua Akhulwe, dan Ceruk Ifeli-feli. Selain menemukan situs, juga ditemukan kapak perunggu di Kwadeware, yang saat ini menjadi koleksi Timotius Marweri tokoh adat Kwadeware (foto 1). Selain itu juga dilakukan survei di Bukit Yomokho untuk menindaklanjuti laporan dari masyarakat bahwa pekerja yang sedang meratakan lereng bukit dengan bulldozer, tanpa sengaja menemukan tulang manusia dan pecahan gerabah. Hasil survei permukaan di Bukit Yomokho didapatkan sisasisa tulang manusia, fragmen gerabah, lapisan konsentrasi moluska danau dan moluska laut (foto 2) serta beberapa bekas tiang rumah berbahan kayu soang (Xanthostemon sp.) yang masih tertancap di tepi danau (foto 3 ) (Tim Peneliti 2010). Temuan permukaan ini belum dapat menjawab peran dan manfaat situs, untuk itu perlu dilakukan ekskavasi, guna mengungkapkan ragam temuan arkeologis yang berada di dalam tanah dan kehidupan manusia pendukung Situs Yomokho. Berdasarkan uraian di atas, muncul pertanyaan: bagaimana keragaman temuan arkeologi di Situs Yomokho dan bagaimana bentuk kehidupan manusia pada masa lalu yang pernah berlangsung di situs tersebut?

Pada dasarnya tujuan ilmu arkeologi dimaksudkan untuk merekonstruksi sejarah kebudayaan, merekonstruksi cara hidup manusia masa lalu dan penggambaran proses perubahan kebudayaan (Binford 1972, 78). Berkaitan dengan hal itu, maka hakikat dari penelitian ini lebih menekankan pada tujuan yang kedua melalui ragam temuan arkeologi yang memberi gambaran bentuk kehidupan manusia yang pernah berlangsung di Situs Yomokho.

Salah satu bentuk lahan yang dipilih manusia sebagai lokasi pemukiman adalah tepian danau, karena memiliki potensi sumberdaya alam yang dapat diandalkan untuk menopang kehidupan sehari-hari. Lokasi pemukiman yang dipilih dekat sumber air, karena air merupakan keperluan pokok makhluk hidup termasuk flora dan fauna. Pemilihan lokasi pemukiman dekat sumber mata air yang memiliki flora dan fauna telah dipertimbangkan sebelumnya agar kebutuhan hidup terpenuhi dari lingkungan sekitar danau.

Menurut cerita dan mitos yang dipercaya masyarakat Sentani, disebutkan bahwa nenek moyang orang Sentani berasal dari Sepik Timur, Papua New Guinea. Pada awal kedatangannya di Danau Sentani, mereka menetap di tiga tempat, yakni Bukit Yomokho, Pulau Ajauw, dan Pulau Kwadeware. Dari ketiga tempat inilah mereka kemudian menyebar ke wilayah Danau Sentani.

Keberadaan persebaran gerabah di sebuah situs, membuktikan bahwa manusia pendukung situs tersebut telah hidup menetap. Pada masa neolitik, gerabah dibuat dengan cara yang sederhana. Teknik yang digunakan dikenal dengan istilah hand-made, yakni suatu teknik pembuatan gerabah yang belum menggunakan alat. Dengan demikian, semua proses pembentukannya dilakukan dengan tangan (Atmosudiro 1998, 4). Pada masa perundagian teknik pembuatan 
gerabah telah lebih maju yaitu sudah dikenalnya tatap pelandas yang dikombinasikan dengan roda putar (Atmosudiro 1994, 14).

Selain berfungsi sebagai peralatan memasak dan menyimpan bahan makanan, gerabah juga berfungsi sebagai bekal kubur dan wadah kubur. Fungsi gerabah dapat dilihat dari bentuknya. Gerabah jenis periuk digunakan untuk memasak sedangkan gerabah jenis tempayan digunakan untuk menyimpan bahan makanan. Gerabah yang berfungsi sebagai bekal kubur, ditemukan secara insitu dengan konteks tulang manusia. Temuan jenis artefak yang bahannya tidak terdapat di lingkungan situs dan tidak diproduksi di sebuah situs, mengindikasikan bahwa artefak tersebut berasal dari luar. Keberadaan artefak dari luar itu dapat digunakan untuk menggambarkan hubungan komunitas danau masa lampau dengan komunitas lain yang hidup di luar komunitas itu.

Pengumpulan data dilakukan dengan beberapa cara, meliputi: 1) studi kepustakaan, yaitu mengumpulkan data tertulis yang berhubungan dengan situs yang diteliti, baik dari publikasi arkeologi maupun penelusuran data dari internet; 2) survei, dengan cara mengamati permukaan tanah dari jarak dekat, untuk mendapatkan data arkeologi dalam konteksnya dengan lingkungan sekitarnya; dan 3) ekskavasi untuk memperoleh bentuk temuan, hubungan antartemuan, hubungan stratigrafis, kronologis tingkah laku manusia pendukungnya, aktivitas manusia pendukungnya setelah temuan terdeposit. Ekskavasi dilakukan dengan teknik spit dengan interval ketebalan 10 centimeter, menggunakan box system dengan ukuran $1 \mathrm{x}$ 2 meter. Ekskavasi dilakukan dengan membuka dua lubang uji (test pit), yang masing-masing diberi nama TP1 dan TP2. Test Pit (TP1) terletak di bukit bagian atas, sedangkan TP2 berada di lereng bukit yang terdapat konsentrasi moluska danau.

Selanjutnya, data artefaktual dianalisis dengan cara mengamati ciri-ciri bentuk, ukuran, warna, teknologi, dan gaya. Sementara itu, untuk mengetahui fungsi artefak dilakukan analisis kontekstual, yaitu mengamati hubungan artefak dengan temuan serta, baik artefak, ekofak, dalam satu matriks (association). Selain itu pengamatan juga dilakukan pada keletakan data arkeologi (provenience), sebaran temuan dalam kotak dan lapisan tanah (stratification).

\section{B. Ekskavasi dan Hasil-hasilnya}

Ekskavasi di Situs Yomokho baru pertama kali dilakukan, sehingga masih bersifat lubang uji dengan tujuan untuk melihat sedalam dan sekompleks apakah kandungan materi arkeologi serta informasi lainnya yang didapat dari situs ini. Pemilihan kotak test pit dilakukan secara selektif (sampling) dengan beberapa pertimbangan logis, seperti kepadatan konsentrasi temuan permukaan; keadaan permukaan tanah; posisi kotak pada situs; dan diperkirakan dapat menghasilkan data yang ingin diketahui. Situs Yomokho merupakan daerah perbukitan, maka dalam pemilihan lubang uji, lokasi kotak TP1 dipilih berada di bagian tengah atas bukit yang memanjang dengan orientasi utara-selatan. Pemilihan lokasi tersebut selain karena posisinya, juga karena pada permukaannya dekat dengan konsentrasi batuan yang tersusun memanjang dari tengah bukit ke 
lereng bukit di sisi timur, serta terdapat beberapa fragmen gerabah. Kotak TP2 dipilih di singkapan tanah pada lereng bukit dengan konsentrasi moluska danau.

Kotak TP1 berhasil digali sedalam 6 spit $(60 \mathrm{~cm})$, temuan berupa fragmen gerabah ditemukan pada spit 2 hingga spit 4 (Tabel 1), spit 5 dan spit 6 dalam kondisi steril temuan. Analisis bentuk terhadap fragmen gerabah yang ditemukan di TP1 menunjukan bentuk periuk dengan tepian terbuka, dibuat dengan teknik roda putar. Kotak TP 2 berhasil digali

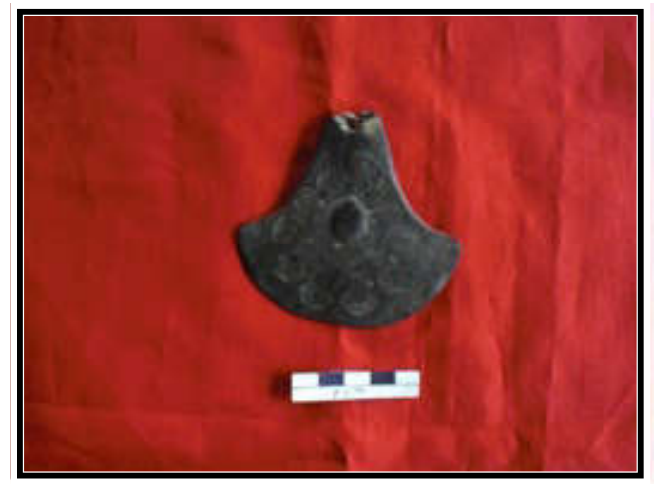

Foto 1. Kapak perunggu koleksi Timotius Marweri

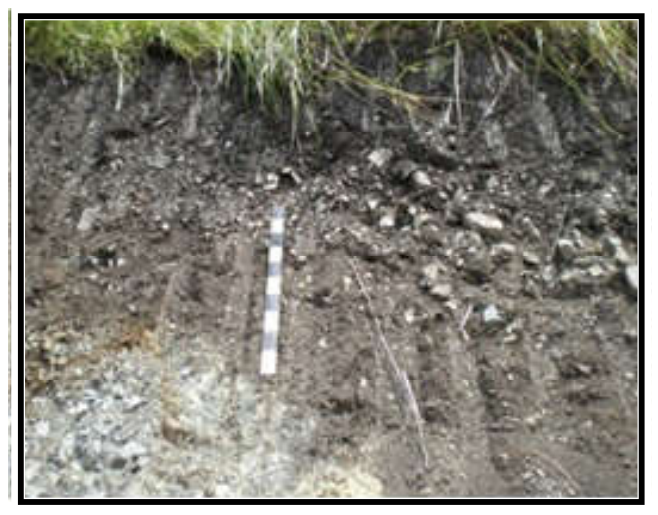

Foto 2. Konsentrasi moluska danau dan moluska laut pada lereng bukit

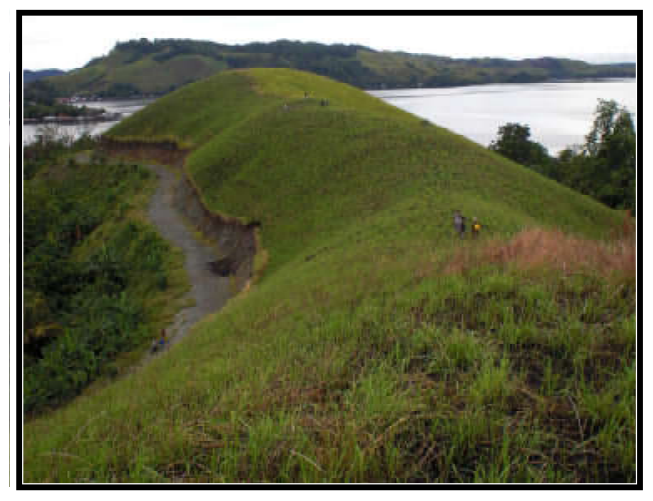

Foto 3. Kondisi lingkungan di sekitar Situs Yomokho

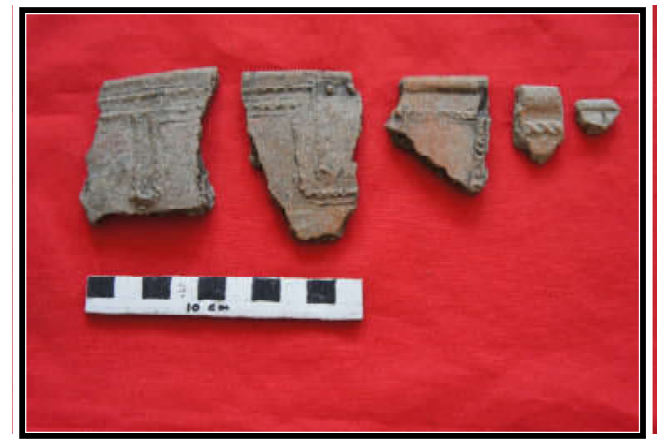

Foto 4. Tepian gerabah hias motif geometris

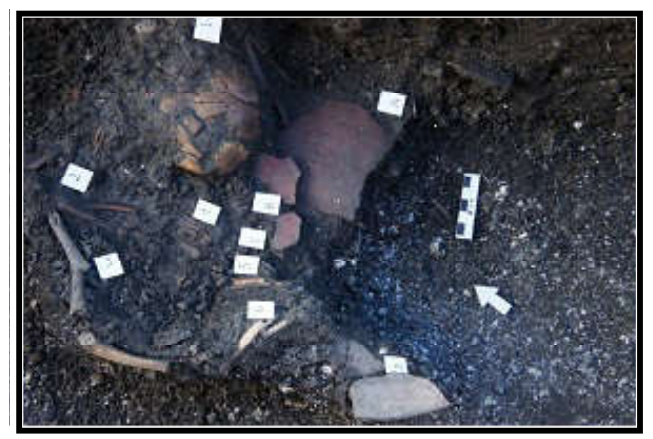

Foto 5. Konsentrasi rangka manusia dan gerabah pada TP2 spit 10 
19 spit, dengan temuan arang, tulang ikan, tulang binatang, tulang manusia, gigi manusia, moluska laut, moluska danau, dan fragmen gerabah (Tabel 2). Pada spit 5, TP2 ditemukan manik-manik berwarna putih, pengerjaannya kasar, penggurdian lubang tengahnya juga nampak kasar. Manik-manik yang ditemukan di spit 5, TP2 Situs Yomokho mengindikasikan bahwa telah terjadi hubungan penduduk tepian danau dengan masyarakat luar. Dalam tradisinya, orang Papua tidak membuat manik-manik. Penggunaan manik-manik sebagai perhiasan, dimungkinkan juga untuk alat tukar dimulai sejak pendukung budaya spit 5 .

Temuan rangka manusia di spit 10 , TP2, yang berasosiasi dengan fragmen gerabah yang berada dalam posisi terbalik di bawah rangka manusia serta terdapat cangkang moluska bercampur arang dan fragmen tulang binatang, mengindikasikan penguburan dengan bekal gerabah. Temuan fragmen gerabah di TP2 menunjukkan bahwa gerabah sudah dipergunakan sejak penghunian awal situs. Berdasarkan analisis bentuk maka terdapat dua jenis gerabah yang ditemukan di Situs Yomokho, yaitu periuk dan tempayan. Gerabah jenis periuk mengindikasikan untuk memasak, hal ini terlihat bekas jejak pakai berupa jelaga, selain itu gerabah jenis periuk ini memiliki konteks temuan arang dan sisa makanan berupa moluska danau, moluska laut, tulang binatang dan tulang ikan. Gerabah jenis tempayan digunakan untuk menyimpan bahan makanan dan air. Ukuran tempayan lebih besar daripada periuk, dan dinding gerabah jenis tempayan lebih tebal daripada periuk. Dinding yang tebal membuat tempayan kuat untuk menyimpan bahan makanan dalam volume banyak.
Analisis teknik pembuatan gerabah jenis tempayan dari Situs Bukit Yomokho berdasarkan pengamatan atas pecahan yang ditemukan terlihat adanya cekungan bekas tekan jari, ketebalan gerabah tidak merata, dan terdapat cekungan bekas pelandas diperkirakan dibuat dengan teknik tatap pelandas. Warna bagian permukaan terdiri atas merah, coklat, dan hitam. Gerabah ini memiliki penampang lintang hitam, diperkirakan dibakar di tempat terbuka. Pengamatan terhadap permukaan fragmen gerabah jenis periuk diketahui terdapat bekas striasi dan permukaan dinding yang halus bekas pengumpaman, hal ini mengindikasikan gerabah jenis periuk dibuat dengan teknik roda putar. Bentuk tepian periuk Situs Yomokho yaitu tepian tertutup dan tepian terbuka.

Pengamatan terhadap kenampakan hiasan pada permukaan fragmen gerabah jenis periuk Stus Yomokho, diketahui motif hias yang dibuat dengan teknik gores yaitu jala (net motive), garis-garis sejajar, duri ikan ganda (fish bone motive), garis-garis sejajar miring berpotongan, garis-garis sejajar lurus berpotongan, jala dibatasi garis lurus, jala dibatasi garis miring, dan motif tumpal. Selain itu juga terdapat motif hias yang dibuat dengan teknik tempel yaitu motif titik, motif garis gelombang dan motif geometris (foto 4).

Konsentrasi temuan yang banyak terdapat di Spit 9 dan 10 (foto 5), ada kemungkinan puncak budaya terdapat pada lapisan budaya spit 9 dan 10. Diperkirakan jumlah populasi yang menghuni Situs Yomokho mengalami peningkatan pada lapisan budaya spit 9 dan 10, populasi yang meningkat membutuhkan bahan makanan 
Tabel 1. Distribusi temuan fragmen gerabah TP 1

\begin{tabular}{|c|c|c|c|}
\hline Spit & Tepian & Badan & Dasar \\
\hline 2 & 1 & 7 & - \\
3 & - & 12 & - \\
4 & - & 2 & - \\
\hline
\end{tabular}

Tabel 2. Distribusi temuan pada TP2

\begin{tabular}{|c|c|c|c|c|c|c|c|c|c|c|c|}
\hline \multirow{2}{*}{ Spit } & \multirow{2}{*}{ Arang } & \multirow{2}{*}{$\begin{array}{c}\text { Tulang } \\
\text { ikan }\end{array}$} & \multirow{2}{*}{$\begin{array}{l}\text { Tulang } \\
\text { hewan }\end{array}$} & \multirow{2}{*}{$\begin{array}{c}\text { Tulang } \\
\text { manusia }\end{array}$} & \multirow{2}{*}{$\begin{array}{c}\text { Gigi } \\
\text { manusia }\end{array}$} & \multirow{2}{*}{$\begin{array}{c}\text { Moluska } \\
\text { laut }\end{array}$} & \multirow{2}{*}{$\begin{array}{c}\text { Moluska } \\
\text { danau }\end{array}$} & \multirow{2}{*}{$\begin{array}{c}\text { Manik- } \\
\text { manik }\end{array}$} & \multicolumn{3}{|c|}{ Gerabah } \\
\hline & & & & & & & & & Tepian & Badan & Dasar \\
\hline 1 & 1 & - & - & - & - & - & - & - & - & 1 & - \\
\hline 2 & - & - & - & - & - & - & - & - & - & 9 & - \\
\hline 3 & 1 & - & - & - & - & - & - & - & 1 & 39 & - \\
\hline 4 & 1 & - & - & - & - & - & - & - & 4 & 74 & - \\
\hline 5 & 1 & - & 1 & - & 1 & 1 & - & 1 & 7 & 139 & - \\
\hline 6 & 1 & - & 2 & - & - & 1 & - & - & 16 & 72 & - \\
\hline 7 & 1 & - & 13 & - & - & 1 & 1 & - & 23 & 61 & - \\
\hline 8 & 1 & 5 & 28 & - & 1 & - & 1 & - & 22 & 43 & 1 \\
\hline 9 & 1 & 10 & 82 & - & 1 & - & 1 & - & 12 & 270 & - \\
\hline 10 & 1 & 5 & 42 & 16 & - & - & 1 & - & 6 & 203 & - \\
\hline 11 & 1 & 4 & 12 & - & - & 1 & 1 & - & 8 & 136 & - \\
\hline 12 & 1 & - & 13 & - & - & 1 & 1 & - & 5 & 124 & - \\
\hline 13 & 1 & 4 & 3 & - & - & - & 1 & - & 4 & 75 & - \\
\hline 14 & 1 & - & - & - & - & 1 & 1 & - & 54 & 51 & - \\
\hline 15 & 1 & - & - & - & - & - & - & - & 2 & 41 & - \\
\hline 16 & 1 & - & - & - & - & - & - & - & 3 & 90 & - \\
\hline 17 & 1 & - & - & - & - & - & - & - & 2 & 50 & - \\
\hline 18 & 1 & - & - & - & - & - & - & - & 2 & 50 & - \\
\hline 19 & 1 & - & - & - & - & - & - & - & - & 1 & - \\
\hline Jumlah & 18 & 28 & 196 & 16 & 3 & 6 & 8 & 1 & 171 & 1528 & 1 \\
\hline
\end{tabular}

yang dikonsumsi dan jumlah peralatan hidup yang diperlukan. Tulang ikan yang ditemukan di spit 9 dan 10, mengindikasikan bahwa manusia pendukung lapisan budaya spit 9 dan 10 telah mengkonsumsi ikan dan diperkirakan telah mengenal teknologi penangkapan ikan. Analisis yang dilakukan oleh Hari Suroto terhadap temuan tulang ikan laut diketahui jenis ikan kakap (Lates calcarifer), ikan sembilang (plotosus anguilaris) dan moluska laut kelas bivalvia famili veneridae membuktikan bahwa manusia pendukung Situs Yomokho telah melakukan hubungan dengan penduduk pesisir pantai, kemungkinan telah mengenal kegiatan tukar menukar dengan penduduk pesisir. Selain itu dalam pencarian bahan makanan, manusia pendukung Situs Yomokho daerah jelajahnya hingga pesisir pantai. 
Berdasarkan temuan berupa sisasisa makanan berupa moluska danau kelas gastropoda famili littorinidae mengindikasikan bahwa moluska danau telah dikonsumsi secara konstan sejak spit 14. Temuan tulang binatang jenis tikus tanah (pogonomelomys), kuskus (phalanger orientalis), tulang ikan, moluska danau, di spit 9 dan 10 TP2 Situs Yomokho menunjukkan bahwa telah terjadi penambahan variasi jenis makanan yang dikonsumsi. Ketrampilan tertentu diperlukan ntuk memperoleh jenis bahan makanan tersebut. Oleh karena itu, dapat diasumsikan bahwa manusia pendukung budaya spit 9 dan spit 10 mulai mengenal teknik-teknik terbaru dalam berburu dan menangkap ikan. Gerabah yang ditemukan di TP2 spit 10 terletak di bawah, tulang ada di atas, hal ini mengindikasikan bahwa gerabah tersebut berfungsi sebagai bekal kubur. Tulang manusia ditemukan di spit 10 TP2 menunjukkan bahwa kedalaman penguburan adalah 100 centimeter dari permukaan tanah. Berdasarkan kuantitas data yang ditemukan dari TP1 dan TP2 Situs Yomokho, menunjukkan bahwa data arkeologi lebih banyak di TP2 yang terletak di lereng bukit, diperkirakan pemukiman terletak di lereng bukit Yomokho, tetapi untuk mendukung interpretasi lebih luas maka perlu dilakukan ekskavasi di beberapa sisi bukit lainnya di situs Yomokho.

\section{Penutup}

Penelitian yang dilakukan di Situs Yomokho berhasil menemukan data arkeologi yang cukup beragam, yaitu fragmen gerabah hias maupun polos, manik-manik, cangkang moluska laut maupun moluska danau, arang, tulang binatang, dan tulang manusia. Temuan-temuan arkeologi tersebut dapat memberi gambaran tentang perilaku dan pemanfaatan situs oleh manusia pendukungnya sebagai hunian. Hal ini didukung pula oleh keadaan lingkungan sekitar situs seperti danau dan hutan sagu sebagai sumber memperoleh makanan. Di Situs Yomokho, selain ekskavasi juga dilakukan survei permukaan yang hasilnya berupa konstruksi jajaran batu yang jika dikaitkan dengan hasil ekskavasi memperkuat bahwa situs tersebut pada masa lalu merupakan pemukiman.

Pola hias gerabah dari Situs Yomokho memiliki kesamaan dengan gerabah dari Gua Skouw Mabo Jayapura, Gua Lachitu, dan Gua Taora di Vanimo Papua New Guinea. Gorecki (1992, 35) dalam Simanjuntak $(1997,944)$ menyatakan bahwa gerabah dari Gua Lachitu dan Gua Taora memiliki pertanggalan 5400 tahun yang lalu, tetapi beberapa peneliti menyangsikan pertanggalan yang dilakukan Gorecki dan mereka percaya pertanggalannya lebih muda.

Pengamatan terhadap bahan artefak gerabah dan perbandingan dengan jenis tanah di Situs Yomokho, tidak memiliki kesamaan sehingga dapat dikatakan bahwa gerabah-gerabah tersebut didatangkan dari luar. Pertanggalan absolut perlu dilakukan terhadap sampel arang dari spit 5, 9, 10, dan 14 kotak TP2 serta sampel moluska laut dari spit 5, 11, 12, 14 kotak TP2. Guna mengetahui ras manusia yang menghuni Situs Yomokho perlu dilakukan analisis laboratoris terhadap tulang manusia yang ditemukan di TP 2 Spit 10. 


\section{Referensi}

Atmosudiro, Sumijati. 1994. Gerabah prasejarah di Liang Bua, Melolo, dan Lewoleba: tinjauan teknik dan fungsinya. Disertasi. Yogyakarta: Universitas Gadjah Mada. , 1998. Manfaat kajian gerabah masa lalu bagi pengembangan kerajinan tembikar sebagai penunjang pariwisata. Berkala Arkeologi XVIII (2): 1-11.

Binford, Lewis R. 1972. Archaeological perspective. New York: Seminar Press.

Soejono, R. P. 1994. Prasejarah Irian Jaya.
Dalam Koentjaraningrat (ed.) Irian Jaya membangun masyarakat majemuk, 23-43.

Simanjutak, Truman. 1997. Review of the prehistory of Irian Jaya. Dalam Miedema, Cecilia Ode dan Rien A. C. Dam (ed.) Prespectiveson the Bird's Head of Irian Jaya, Indonesia, 941950.

Tim Peneliti. 2010. Laporan penelitian arkeologi prasejarah di Sentani. Jayapura: Balai Arkeologi Jayapura. Belum diterbitkan. 